\title{
KARAKTERISASI BAKTERI ASAM LAKTAT (BAL) DARI FERMENTASI TAPE SINGKONG
}

\author{
Widya Rahmah ${ }^{1}$, Erika Nandini ${ }^{1}$, Sylvan Septian Ressandy ${ }^{1}$, Hasyrul Hamzah ${ }^{1 *}$ \\ ${ }^{1 *}$ Fakultas Farmasi, Universitas Muhammadiyah Kalimantan Timur, Jl. Ir. H. Juanda No.15, Samarinda, (0541) 748511 \\ e-mail: 1*hh241@umkt.ac.id
}

\begin{abstract}
ABSTRAK
Indonesia terkenal dengan berbagai macam makanan tradisional fermentasi. Jenis makanan tradisional fermentasi yang banyak dijumpai adalah tape singkong yang berbahan pangan karbohidrat menggunakan ragi khamir yang termasuk kelompok bakteri asam laktat (BAL). Penelitian ini bertujuan untuk mengisolasi dan mengkarakteristik BAL sebagai probiotik dari makanan fermentasi tape singkong. Metode penelitian yang dilakukan yaitu pembuatan suspensi sampel, isolasi dan pemurnian mikroba, pengamatan sifat morfologi koloni, pengecatan gram isolat bakteri, uji ketahanan terhadap keasaman, serta uji ketahanan terhadap garam empedu. Berdasarkan hasil penelitian dari 4 jenis sampel dengan pengenceran yang berbeda-beda, uji makroskopik pada semua sampel memiliki bentuk tepi koloni irregular dengan 3 jenis sampel bentuk evelasi koloni umbonate dan 1 sampel spreading, serta 2 sampel bentuk koloni umbonate dan 2 lainnya spreading. Pada uji mikroskopik, semua sampel termasuk dalam golongan bakteri Gram positif dan berbentuk batang. Sedangkan pada uji karakteristik isolat probiotik terhadap pH dan garam empedu menggunakan medium MRSB dengan dua variasi $\mathrm{pH}$ yang berbeda yaitu $\mathrm{pH}$ 2,5 dan $\mathrm{pH} 3$, didapatkan hasil bahwa terdapat endapan pada pertumbuhan isolat dimana uji terhadap keasaman yang menyatakan bahwa BAL telah memenuhi semua persyaratan pengujian probiotik. Tetapi pada uji ketahanan garam empedu, keseluruhan isolat lebih optimal tumbuh pada medium yang mengandung ox bile 1\% dibandingkan dengan konsentrasi 5\%. Oleh karena itu tape singkong dapat dijadikan sebagai salah satu sumber bakteri asam laktat sebagai probiotik.
\end{abstract}

Kata kunci : Bakteri Asam Laktat, Isolasi, Karakterisasi, Probiotik, Tape

\begin{abstract}
Indonesia is famous for its wide variety of fermented traditional foods. The type of traditional fermented food that is often found is cassava tape which is made from carbohydrate food using yeast which belongs to the lactic acid bacteria (LAB) group. This study aims to isolate and characterize LAB as probiotics from fermented cassava tape food. The research methods used were the manufacture of sample suspensions, isolation, and purification of microbes, observation of the morphology of the colonies, gram staining of bacterial isolates, acid resistance test, and bile salt resistance test. Based on the results of research from 4 types of samples with different dilutions, macroscopic tests on all samples had irregular colony edge shapes with 3 types of samples of umbonate colony elevation and 1 spreading sample, as well as 2 samples of umbonate colony shape and 2 others spreading. In the microscopic test, all samples belonged to the Gram-positive bacteria group and were rod-shaped. Meanwhile, in the characteristic test of probiotic isolates against $\mathrm{pH}$ and bile salts using MRSB medium with two different $\mathrm{pH}$ variations, namely $\mathrm{pH} 2.5$ and $\mathrm{pH} 3$, the results showed that there were deposits on the growth of the isolates where the acidity test stated that LAB had met all the test requirements. probiotics. However, in the bile salt resistance test, all isolates grew more optimally on a medium containing $1 \%$ ox bile compared to $5 \%$ concentration. Therefore, cassava tape can be used as a source of lactic acid bacteria as probiotics.
\end{abstract}

Keywords : Characterization, Isolation, Lactic Acid Bacteria, Probiotics, Tape

\section{PENDAHULUAN}

Indonesia terkenal dengan berbagai macam makanan tradisional fermentasi yang tersedia di pasar tradisional maupun pasar moderen. Kebanyakan makanan tradisional fermentasi tersebut diproduksi dalam skala kecil atau skala rumah tangga (Surbakti \& Hasanah, 2019). Jenis makanan tradisional yang banyak dijumpai yang diproses dengan menggunakan proses fermentasi adalah tape atau tapai singkong. Tape singkung merupakan kudapan yang dihasilkan dari proses fermentasi substrata tau bahan pangan berkarbohidrat menggunakan ragi khamir yang termasuk kelompok bakteri asam laktat (Sulistiani, 2020).

Bakteri asam laktat (BAL) adalah kelompok bakteri Gram positif, tidak berspora, berbentuk bulat atau batang dan dapat mengubah karbohidrat menjadi asam laktat (DeVuyst \& Leroy, 2007). Bakteri asam laktat (BAL) termasuk mikroorganisme yang aman jika ditambahkan dalam pangan karena tidak menghasilkan toksin, atau dikenal sebagai mikroorganisme yang Generally Recognized As Safe (GRAS) yaitu mikrorganisme yang tidak beresiko terhadap kesehatan (Koriasih \& Jannah, 2019). BAL selain penghasil bakteriosin juga memberikan efek fisiologis bagi kesehatan (Amin et al., 2011).

Di Indonesia telah banyak dilaporkan hasil penelitian yang mengungkap potensi bakteri asam laktat sebagai hasil substansi antimikrobia dari bahan makanan hasil fermentasi dan salah satunya adalah tape atau tapai singkong (Papuangan, 2014). Pemanfaatan BAL selain dalam industri makanan sebagai agen 
sintesa bakteriosin dalam biopreservatif juga memberikan kontribusi yang besar di bidang kesehatan seperti pengobatan mikroorganisme yang membentuk biofilm penyebab utama penyakit kronis (Hamzah et al., 2020) dengan berperan sebagai agen antibiotik alami dan pangan probiotik (Surbakti \& Hasanah, 2019). Peranan bakteri asam laktat sebagai probiotik bagi kesehatan manusia dan hewan antara lain menurunkan kasus intoleransi laktosa, menurunkan kadar serum kolesterol, mengurangi frekuensi terjadinya penyakit diare, menstimulasi sistem imunitas tubuh, mengendalikan infeksi patogen, mampu berperan sebagai pengganti antibiotik, serta mampu menekan terjadinya tumor dan kanker sistem pencernaan dengan cara memelihara keseimbangan mikroba dalam sistem pencernaan (Manalu et al., 2020).

Seiring dengan berjalannya waktu terjadi pergeseran pola makan masyarakat modern dengan konsumsi bahan makanan yang mengandung protein dan lemak yang tinggi serta kandungan serat yang rendah diduga salah satu pemicu munculnya berbagai penyakit yang berhubungan dengan saluran pencernaan. Untuk menggantikan obat-obatan modern dalam menjaga kesehatan dan mengobati penyakit (Hamzah et al., 2021). Salah satu upaya yang dilakukan adalah dengan modifikasi komposisi bakteri saluran pencernaan yang dapat dilakukan melalui konsumsi bakteri hidup sehingga dapat menjaga keseimbangan bakteri yang menguntungkan di dalam saluran percernaan yang disebut bakteri probiotik, Dalam tubuh manusia, bakteri dalam dilindungi sistem kekebalan dan pengobatan antibiotic (Pratiwi \& Hamzah, 2020), dan bakteri probiotik ini didapatkan dari jenis bakteri asam laktat yang diketahui berada pada Tape ketan yang merupakan salah satu sumber untuk isolasi bakteri asam laktat (Koriasih \& Jannah, 2019).

Berdasarkan alasan di atas maka penulis tertarik untuk melakukan penelitian tentang isolasi dan karakteristik bakteri asam laktat sebagai probiotik pada makanan fermentasi tape singkong untuk memperkirakan genus dari isolat bakteri asam laktat, serta mempermudah penelitian mendatang dalam pengujian kelayakan Isolat bakteri asam laktat pada tapai atau tape singkong sebagai kandidat probiotik atau sebagai bakteriosin.

\section{METODE PENELITIAN}

\subsection{Pembuatan Suspensi Sampel}

Sampel tape singkong ditimbang 1 gram kemudian dimasukkan ke dalam botol pengencer dan ditepatkan hingga $10 \mathrm{ml}$ dengan aquades steril dan diencerkan dari $10^{-1}$ sampai $10^{-4}$.

\subsection{Isolasi dan Pemurnian Mikroba}

$\mathrm{CaCO} 3$ 1\% ditambahkan ke dalam media steril agar Regosa Sharpe. Keluarkan $1 \mathrm{ml}$ pengenceran $10^{-1}$, $10^{-2}, 10^{-3}$, dan $10^{-4}$ dari suspensi sampel yang telah disiapkan, masukkan ke dalam cawan petri steril, kemudian tuangkan $9 \mathrm{~mL}$ MRSA, lalu homogenkan dengan cara dikocok hingga terbentuk delapan Jenis huruf. Kemudian diinkubasi terbalik pada suhu $37^{\circ} \mathrm{C}$ selama 1-3 $\times 24$ jam. Koloni yang telah dipisahkan kemudian dimurnikan dengan metode kuadran, kemudian dipindahkan ke media kultur dan dimiringkan sebagai larutan stok.

\subsection{Pengamatan Sifat Morfologi Koloni}

Isolat bakteri dicirikan dengan tumbuh pada media kultur. Amati pertumbuhan koloni pada media kultur dan tegakkan, yaitu bentuk pertumbuhan pada bekas tusukan yaitu bentuk, tepi, benjolan, koloni (Rozirwan, 2009) Dalam Ismail, 2014).

\subsection{Pengecatan Gram Isolat Bakteri}

Kaca target dibersihkan dengan etanol $70 \%$ dan ditambahkan air suling, kemudian dipanaskan di atas api. Dalam kondisi aseptik, ambil 1 ose biakan bakteri, ratakan pada kaca objek dan pasang di atas api. Kemudian tambahkan larutan cristal violet (A g) tetes demi tetes, diamkan selama 1 menit, lalu cuci dengan air mengalir dan keringkan. Tambahkan larutan iodium (Gram B) tetes demi tetes dan diamkan selama 1 menit, lalu cuci dengan air mengalir dan keringkan. Kemudian cuci dengan larutan pemutih (Grade C) selama 30 detik, cuci dengan air mengalir dan keringkan. Setelah itu, tambahkan larutan flavin (Gram D) atau bahan penutup tetes demi tetes, diamkan selama 2 menit, lalu cuci dengan air mengalir dan keringkan. Kemudian amati dengan mikroskop dengan perbesaran kuat (Irianto, 2006).

\subsection{Uji Ketahanan terhadap Keasaman}

Ekstrak isolat bakteri hingga 1 ose (ose bulat) dari stok. Kemudian diinokulasikan pada media MRSB$\mathrm{HCl}$ dan diinkubasi pada suhu $37^{\circ} \mathrm{C}$ selama $2-3 \times 24$ jam. Pertumbuhan bakteri pada media dengan keasaman rendah ( $\mathrm{pH} 2,5$ - 3) menunjukkan hasil yang positif. Jika tidak ada pertumbuhan mikroorganisme pada media maka hasilnya negatif (Djide \& Wahyuddin, 2008).

\subsection{Uji Ketahanan terhadap Garam Empedu}

Metodenya adalah dengan menambahkan 1\% dan 5\% garam empedu sintetik (empedu sapi) ke dalam medium MRSB, dan mengeluarkan isolat bakteri lose dari larutan stok dan menginokulasikan garam empedu medium MRSB. Inkubasi pada suhu $37^{\circ} \mathrm{C}$ selama $2-3 \times$ 24 jam. Resistensi terhadap garam empedu ditentukan oleh ada tidaknya pertumbuhan bakteri dalam medium. Hasil positif ditunjukkan dengan adanya endapan pada dasar tabung (Djide \& Wahyuddin, 2008).

\section{HASIL DAN PEMBAHASAN}

\subsection{Pemurnian Isolat Mikroba}

Pada hasil pemurnian isolat mikroba, koloni mikroba yang diperoleh menunjukkan adanya zona 
Jurnal Penelitian Farmasi Indonesia 10(1), Juni 2021

ISSN : 2302-187X e-ISSN 2656-3614

bening disekeliling koloninya. Selanjutnya digoreskan pada medium MRSA lalu diinkubasi selama 2-3 $\times 24$ jam pada suhu $37^{\circ} \mathrm{C}$. Setelah itu, diperoleh 4 kultur koloni isolat bakteri asam laktat (BAL) yang murni hasil inkubasi. Hasil pemurnian isolat bakteri asam laktat (BAL) dapat dilihat pada tabel 1.

Tabel 1. Hasil Pemurnian Isolat Tape Singkong Bakteri Asam Laktat

\begin{tabular}{ccc}
\hline No & Kode Bakteri & Biakan Bakteri \\
\hline 1 & SK 1 & Isolat Bakteri ke-1 \\
2 & SK 2 & Isolat Bakteri ke-2 \\
3 & SK 3 & Isolat Bakteri ke-3 \\
4 & SK 4 & Isolat Bakteri ke-4 \\
\hline
\end{tabular}

Keterangan :

SK 1 : Isolat bakteri ke-1

SK 2 : Isolat bakteri ke-2

SK 3 : Isolat bakteri ke-3

SK 4 : Isolat bakteri ke-4

\subsection{Uji Makroskopik}

Pada uji makroskopik, isolat bakteri asam laktat (BAL) yang memiliki pencirian yang berbeda diamati dengan melihat bentuk koloni, elevasi koloni, dan tepi koloni. Hasil dari makroskopik dapat dilihat pada tabel 2 .

Tabel 2. Hasil Makroskopik Tape Isolat Bakteri Asam Laktat

\begin{tabular}{cccc}
\hline $\begin{array}{c}\text { Kode } \\
\text { Jamur }\end{array}$ & Tepi & Elevasi & Bentuk Koloni \\
\hline SK1 & Irregular & Umbonate & Umbonate \\
SK 2 & Irregular & Umbonate & Spreading \\
SK 3 & Irregular & Spreading & Spreading \\
SK 4 & Irregular & Umbonate & Umbonate \\
\hline
\end{tabular}

Keterangan :

TP 1 : Isolat bakteri ke-1

TP 2 : Isolat bakteri ke-2

TP 3 : Isolat bakteri ke-3

TP 4 : Isolat bakteri ke-4

Wavy : Beromak

$\begin{array}{ll}\text { Irregular } & : \text { Tidak beraturan } \\ \text { Umbunate } & : \text { Ada tonjolan } \\ \text { Spreading } & : \text { Menyebar } \\ \text { Lobate } & : \text { Berkeluk-keluk }\end{array}$

\subsection{Uji Mikroskopik}

Pada uji mikroskopik, isolat bakteri asam laktat (BAL) yang menunjukkan zona bening diambil dengan cara mikroskopik untuk melihat warna dan bentuk sel isolat mikroba. Warna ungu menunjukkan bakteri Gram positif, sedangkan warna merah menunjukkan bakteri Gram negatif. Hasil dari mikroskopik dapat dilihat pada tabel 3.

Tabel 3. Hasil Pemurnian Isolat Tape Singkong Bakteri Asam Laktat

\begin{tabular}{cccc}
\hline $\begin{array}{c}\text { Kode } \\
\text { Jamur }\end{array}$ & Warna & $\begin{array}{c}\text { Mikroskopik } \\
\text { Bentuk }\end{array}$ & Keterengan \\
\hline SK1 & Ungu & Batang & Gram Positif \\
SK 2 & Ungu & Batang & Gram Positif \\
SK 3 & Ungu & Batang & Gram Positif \\
SK 4 & Ungu & Batang & Gram Positif \\
\hline
\end{tabular}

Keterangan :

TP 1 : Isolat bakteri ke-1

TP 2 : Isolat bakteri ke-2

TP 3 : Isolat bakteri ke-3

TP 4 : Isolat bakteri ke-4

\subsection{Karakterisasi Bakteri Asam Laktat (BAL) sebagai Probiotik}

Hasil dari isolat bakteri asam laktat (BAL) sebagai probiotik yang telah diperoleh ini dikarakterisasi dengan metode uji biokomia yaitu uji ketahanan asam $(\mathrm{pH})$, uji ketahanan garam empedu, dan isolat BAL. Hasil karakterisasi bakteri asam laktat sebagai probiotik dapat dilihat pada tabel 4 .

Tabel 4. Hasil Karakterisasi Tape Ketahanan Asam dan Garam Empedu Bakteri Asam Laktat sebagai Probiotik dari Produk Fermentasi

\begin{tabular}{cccccc}
\hline $\begin{array}{c}\text { Kode } \\
\text { Isolat }\end{array}$ & \multicolumn{2}{c}{ Ketahanan } \\
Asam (pH) & \multicolumn{2}{c}{$\begin{array}{c}\text { Ketahanan } \\
\text { Garam }\end{array}$} & $\begin{array}{c}\text { Isolat } \\
\text { BAL }\end{array}$ \\
& 2.5 & 3 & $1 \%$ & $5 \%$ & \\
SK 1 & + & + & + & ++ & + \\
SK 2 & + & + & ++ & + & + \\
SK 3 & ++ & + & ++ & + & + \\
SK 4 & ++ & + & ++ & + & + \\
\hline
\end{tabular}

Keterangan :

TP 1 : Isolat bakteri ke-1

TP 2 : Isolat bakteri ke-2

TP 3 : Isolat bakteri ke-3

TP 4 : Isolat bakteri ke-4 
Jurnal Penelitian Farmasi Indonesia 10(1), Juni 2021

ISSN : 2302-187X e-ISSN 2656-3614

$$
\begin{array}{ll}
+++ & : \text { Sangat keruh dan banyak endapan } \\
++ & : \text { Keruh dan cukup banyak endapan } \\
+\quad & : \text { Keruh dan sedikit endapan }
\end{array}
$$

Bakteri asam laktat (BAL) merupakan suatu bakteri anaerob fakulatif yang mampu hidup dalam berbagai habitat yang cukup luas di alam seperti pada tanaman, saluran pencernaan, produk makanan kalengan, produk susu, produk fermentasi, buahbuahan, sayur-sayuran tropis, dan lain sebagainya.

Suplemen pakan yang berisi mikrobia hidup (directed microbials) merupakan probiotik yang memiliki banyak manfaat bagi kehidupan. Probiotik ini merupakan mikroorganisme hidup yang jika dikonsumsi oleh inang maka akan memberikan pengaruh yang menguntungkan dengan memperbaiki lingkungan mikrobiota yang ada di dalam sistem pencernaan.

Dalam penelitian ini, digunakan metode isolasi yaitu metode tuang dimana tape dibuat beberapa pengenceran dimulai dari pengenceran $10^{-1}$ sampai $10^{-4}$. Dibuat pengenceran yang berbeda-beda adalah untuk mendapatkan konsentrasi yang berbeda dan mengurangi tingkat kontaminasi sehingga dapat memudahkan pengamatan bakteri atau koloni yang tumbuh.

Berdasarkan hasil isolasi dan inkubasi selama 48 jam didapatkan 4 koloni. Setelah kkloni mikroorganisme didapatkan, kemudian dilakukan pemurnian isolat mikroba dengan cara digores pada medium MRSA, yang mengandung nutrisi yang diperlukan mikroba yang cocok untuk pertumbuhan bakteri asam laktat. Dalam pengujian ini, 4 koloni tape menunjukkan adanya zona bening di sekeliling koloninya. Menurut Gobel (2005) dalam Djide dan Wahyudin (2008), setelah diinkubasi selama 2-3 hari akan didapatkan hasil adanya zona bening disekitar koloni untuk seleksi bakteri asam laktat. Hal ini dikarenakan bakteri asam laktat menghasilkan asam laktat yang akan bereaksi dengan $\mathrm{CaCO}_{3}$, sehingga setelah masa inkubasi 2-3 hari akan muncul daerah zona bening disekitar koloni yang tumbuh pada media akibat terbentuknya Ca-laktat yang larut dalam media.

Setelah diperoleh 4 isolat biakan murni, dipindahkan isolat pada medium agar miring sebagai simpanan stok. Setelah itu, dilakukan penelitian secara makroskopik untuk mengetahui bentuk morfologi isolat mikroba yang diteliti sehingga dapat diketahui dengan pasti bahwa keempat isolat yang telah didapat berbeda jenisnya, dimana diketahui bentuk tepi koloni pada kode jamur SK 1, SK 2, SK 3 dan SK 4 adalah irregular atau tidak beraturan. Sedangkan pada bentuk evelasi koloni pada kode jamur SK 1, SK 2, dan SK 4 adalah umbonate atau ada tonjolan, dan pada kode jamur SK 3 adalah spreading atau menyebar. Kemudian pada bentuk koloni untuk kode jamur SK 1 DNA sampel SK 4 adalah umbonate atau ada tonjolan, tetapi pada kode jamur SK 2 dan SK 4 adalah spreading atau berkeluk-keluk.
Setelah dilakukan uji makrosopik, dilakukan pengamatan secara mikroskopik dengan pengecatan Gram dan pengamatan dibawah mikroskop. Hal ini dilakukan untuk menentukan bakteri tersebut termasuk golongan bakteri Gram positif atau Gram negatif. Berdasarkan hasil pengecatan Gram tersebut menunjukkan bahwa semua sampel isolat merupakan bakteri Gram positif yang ditandai dengan sel bakteri yang berwarna ungu disertai bentuk sel yang sama yaitu batang (basil). Menurut Surono (2004), variasi karakteristik bakteri asam laktat normal terjadi, tetapi sifatnya sebagai bakteri Gram positif adalah mutlak. Diketahui bahwa bakteri asam laktat (BAL) yang berbentuk batang (rod) tergolong Lactobacillus, sedangkan yang berbentuk kokus (cocci) tergolong Lactococcus, Streptococcus, Leuconostoc, Enterococcus dan Pediococcus.

Pada persyaratannya, mikroba kandidat probiotik harus mampu bertahan terhadap kondisi ekstrim seperti dalam saluran pencernaan mulai dari mulut hingga mencapai usus. Fuller (1989) menyatakan bahwa pensyaratan bakteri asam laktat (BAL) lainnya yang digunakan sebagai agensia probiotik harus memiliki sifat toleran terhadap asam, empedu dan panas, serta mampu tumbuh dengan cepat dan memproduksi asam dalam jumlah yang besar pada jalur intestine.

Kemudian, dilakukan uji karakteristik isolat probiotik terhadap $\mathrm{pH}$ dan garam empedu dengan menggunakan medium MRSB. Didapatkan hasil bahwa terdapat adanya endapan pada pertumbuhan isolat dimana uji terhadap keasaman menggunakan dua variasi $\mathrm{pH}$ yang berbeda yaitu $\mathrm{pH} 2,5$ dan $\mathrm{pH} 3$. Menurut Itoh (1992) dalam Harimurti et al (2007), isolate bakteri asam laktat memiliki standar yang digunakan sebagai agensia probiotik. Standar tersebut adalah isolat harus mampu bertahan pada $\mathrm{pH} 3$, selama 2 jam. Selain itu menurut Drasar dan Barrow (1985), saluran pencernaan memiliki kondisi $\mathrm{pH}$ terendah yang diperkirakan pada gizzard mencapai 2,5.

Berdasarkan hasil isolasi bakteri dari produk fermentasi tape, diketahui bahwa keempat isolat mampu bertahan pada $\mathrm{pH}$ 2,5 dan $\mathrm{pH} 3$ serta semua hasilnya positif. Pada tabel 4 menunjukkan bahwa ketahanan isolat berbeda-beda terhadap kondisi keasaman medium. Selain itu, pada uji ketahanan garam empedu berdasarkan hasil pada tabel 4 menujukkan bahwa keempat sampel isolat mampu bertahan dan tumbuh pada medium yang mengandung garam empedu sintetik (Ox Bile) dengan perbedaan konsentrasi $1 \%$ dan $5 \%$. Tetapi diketahui bahwa keseluruhan isolat lebih optimal tumbuh pada medium yang mengandung ox bile $1 \%$ dibandingkan dengan konsentrasi $5 \%$.

\section{SIMPULAN}

Hasil isolasi bakteri asam laktat dari makanan fermentasi tapai/tape menunjukkan semua isolat positif bakteri probiotik. 
Jurnal Penelitian Farmasi Indonesia 10(1), Juni 2021
ISSN : 2302-187X
e-ISSN 2656-3614

\section{UCAPAN TERIMA KASIH}

Terima kasih banyak kami ucapkan kepada Fakultas Farmasi Universitas Muhammadiyah Kalimantan Timur yang selalu mewadahi kami dalam segala kegiatan.

\section{DAFTAR PUSTAKA}

Amin, H., Saida, Suriyanti, Suherah, \& Gani, M. 2020. Isolasi dan karakterisasi bakteri probiotik dari saluran pencernaan ayam kampung (Gallus domesticus), Jurnal AGrotekMAS, 1(1): 7581 .

DeVuyst, L., \& Leroy, F. 2007. Bacteriocins from Lactic Acid Bacteria: Production, Purification, and Food Applications, $J$ Molec Microbiol Biotechnol. 13: 194-199.

Djide, M. N., \& Wahyudiin, E. 2008. Isolasi Bakteri Asam Laktat dan Air Susu Ibu dan Potensinya dalam Penurunan Kadar Kolestrol secara In Vitro, Majalah Farmasi dan Farmakologi, 12(3): 7378.

Drasar, B. S., \& Barrow, P. A. 1985. Intestinal Microbiology. American Society for Microbiology. Washigton: American Society dor Microbiology.

Fuller, R. 1989. A Review Probiotic in Man and Animals, Journal of Applied Bacteriology, 66: 365-378.

Harimurti, S., Endang S. R., Nasroedin, \& Kurniasih. 2007. Bakteri Asam Laktat dari Intestin Ayam Sebagai Agensia Probiotik, Animal Production, 9(2): 82-91

Irianto, K. 2007. Mikrobiologi Menguak Dunia Mikroorganisme. Jilid 2, Bandung: CV. Irama Widya.

Ismail, 2014. Deteksi Bakteri Burkholderia pseudomallei Penyebab Penyakit melioi dosis dari Pasien Infeksi Radang Paru dengan Teknik Polymerase Chain Reaction (PCR), Skripsi, Universitas Muslim Indonesia, Makassar.
Koriasih, P., \& Jannah, S. N. 2019. Isolasi bakteri asam laktat dari tape ketan dan potensinya sebagai agen antikapang terhadap pertumbuhan Aspergillus flavus Isolation of lactic acid bacterial from fermented sticky rice and its potency as agent of anti-fungus against Aspergillus flavus gro, NICHE Journal of Tropical Biology, 2(10): 7-13.

Manalu, R. T., Bahri, S., \& Sarah, S. 2020. Isolasi dan Karakterisasi Bakteri Asam Laktat asal Feses Manusia sebagai Antibakteri Escherichia coli dan Staphylococcus aureus, Sainstech Farma, 13(1): 55-59.

Papuangan, N. (2014). Potensi Senyawa Antibakteri Isolat Bakteri Asam, Seminar Nasional Riset Inovatif II, 01(2339-1553), 1 15 .

Sulistiani, H. I. 2020. Identifikasi molekuler Bakteri Asam Laktat dari Tempe dan Tape Berdasarkan Sekuen Gen 16S rRNA, Majalah Ilmiah Biologi Biosfera : A Scientific Journal, 37(2): 69-77.

Surbakti, F. H., \& Hasanah, U. (2019). Identifikasi dan Karakterisasi Bakteri Asam Laktat pada Acar Ketimun (Cucumis sativus L.) sebagai Agensi Probiotik, Jurnal Teknologi Pangan Keseheatan, 1: 31-37.

Surono, I.. S. 2004. Probiotik Susu Fermentasi dan Kesehatan, Jakarta: Tri Cipta Karya

Hamzah, H., Hertiani, T., Pratiwi, S. U. T., \& Nuryastuti, T. (2020b) Efficacy of Quercetin against Polymicrobial Biofilm on Catheters, Research Journal of Pharmacy and Technology, 13(11), 5277-5282

Pratiwi, S. U. T., \& Hamzah, H. (2020). Inhibition and Degradation Activity of (Sapindus rarak seeds) ethanol extract against polymicrobial biofilm, Research Journal of Pharmacy and Technology, 13(11), 5425-5430.

Hamzah, H., Hertiani, T., Pratiwi, S. U. T., \& Nuryastuti, T. (2020). Efek Saponin Terhadap Penghambatan Planktonik Dan MonoSpesies Biofilm Candida albicansATCC 10231 Pada Fase Pertengahan, Pematangan Dan Degaradasi, Majalah Farmaseutik, 17(2), 198-205 